\title{
A PHONETICO-SEMANTIC ANALYSIS OF VERB-NOUN CONTRACTIONS IN YORUBA ${ }^{1}$ \\ B. Rotimi Badejo \\ Univeristy of Maiduguri, Nigeria
}

\begin{abstract}
This paper highlights the various studies which have been carried out to determine the rules which govern the elision of one of the vowels in a verb-noun concatenation where the verb is vowel-final and the noun vowel-initial. It proposes that there are basically three phonological rules which come into play at the Deep Structure Level. However, at the Surface Structure Leve1, the paper recognizes that there is a Semantic Dissimilation Principle (SDP), which may block the application of otherwise well-motivated rules. The SDP, then, guarantees maximal perceptual distance between otherwise homophonous products of the phonological rules.
\end{abstract}

\section{Introduction}

Quite a significant number of authors have given some attention to verbnoun contractions in Yoruba-Bowen [1858], Bamgbose [1965], Rowlands [1969], Courtenay [1969], Oyelaran [1972]. But up till now, no one has been able to produce a satisfactory formulation of the rules which govern the elision of one of the vowels in a verb-noun concatenation where the verb is vowel-final and the noun vowel-initial.

From the outright pessimism of Rowlands [1954:384]:

"An examination of the cases of elision soon makes it clear that at the phonological level of analysis it is impossible to formulate any rule as to which vowel survives ..."

to the cautious optimism of Bamgbose [1972:13]:

${ }^{1}$ This paper is partly based on experimental phonetic research carried out at the Université de Montréal, Canada between 1979 and 1980 . 
"Perhaps future research on this subject should probe more deeply possible lexical and semantic factors that influence which vowel is elided or retained in these verb-noun combinations"

there have been interesting conclusions drawn from studies of verb-noun contractions in Yoruba.

In this paper, we shall first consider the salient points in previous studies (especially those by Bamgbose and Oyelaran), before attempting to propose a new analysis that eliminates the thorny problem of "exceptions" which pervade previous proposals.

\section{Previous Studies}

Oyelaran [1972] gives quite a detailed review of relevant literature to the topic under discussion. He also rightly suggests that while Rowland's approach is mainly syntactic, judging by such statements as

"... we can explain the difference in treatment between bímọ and bọmọ by saying that in the first our attention is focused on the verbal, in the second, on the nominal ..." [Rowlands 1954:384]

Courtenay's is based on a criterion of "familiarity" that determines which verbs elide their final vowel and which do not. That is, the less familiar a verb is, the more likely it is to lose its vowel.

1.1. Bamgbose's proposal. As for Bamgbose's "principles of contraction", Oyelaran justifiably attempts to prove that their inventory is "observational and taxonomic". One can easily observe that some of Bamgbose's principles are inconclusive: "the vowel $i$ whether of the verb or of the nominal is almost always elided"; while others betray analytical disorder: "the vowel a of a verb having a high tone is usually retained, except in the case of bá and wá where the vowel is elided" (that is, tone is a determinant of vowel elision!). However, Bamgbose's major contribution lies in his categorization of Yoruba verb-noun combinations into three groups: (1) those in which the vowels in contact are identical, (2) those that are always contracted, (3) those whose vowels in contact are not identical, and are not always contracted. Although Oyelaran replaces this tripartite approach with a bipartite one, the 
basis of his work owes a lot to that of Bamgbose (and of course, Rowlands, as he himself points out).

1.2. Oyelaran's proposal. The cornerstone of Oyelaran's analysis of verbnoun contractions is his binary approach. He proposes that verb-noun combinations belong to two groups: Group I, consisting of such combinations which are analyzable as verbs alone and therefore, cannot be split up; and Group II, others that can be split up into "verb and noun". Despite its analytical appeal, Oyelaran's proposal has a major problem, that of determining what combinations belong to which group since some of them appear to be "amphibious" [Bamgbose 1972:12].

We may also add that it is in treating "apparent exceptions" (to his rules) that Oyelaran stumbles on what should have been his guiding-1ight, viz. vowel quality, which, unfortunately, remains idle throughout the formulation of his rules:

"In the case of verb + noun, (VP), vowel elision is optional, and when it takes place, it is the vowel quality (non-tonal features) of verb final vowel features that are neutralized" [Oyelaran 1972:189].

Nonetheless, Oyelaran should be credited for proposing that vowels and tones should be treated as "autosegments" (though he does not use the term), each independent of the other in Yoruba [Badejo 1979; Akinlabi 1982]. Regretably, Oyelaran does not adhere strictly to this principle in his analysis.

\section{A New Approach}

It is our aim to re-orient research on this topic and put it on the path that may lead to a permanent solution. That is, since our main object is to determine the cases when the contraction of vowels does or does not take place, our concern should be with vowel quality and not the grammatical status of the segments (such as verb or noun) to which these vowels belong. This notion is very crucial for an adequate understanding of our analysis because it is precisely this change of focus which distinguishes our approach from earlier analyses. This means then, that we will concern ourselves with the phonological nature of the vowels in contact, irrespective of the lexical 
items to which those vowels may belong.

2.1. Yoruba oral vowel system. ${ }^{2}$ Standard Yoruba ${ }^{3}$ is said to operate a system of seven oral vowels which may be represented as follows: 4

(1)

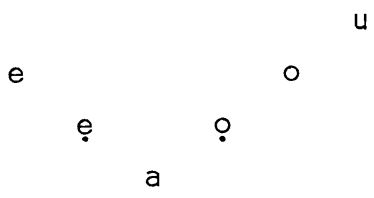

See Bamgbose [1965] for an accurate phonological description of all of them.

2.2. Vowel distribution. Generally, there are certain distributional restrictions on particular vowels. A consideration of these will permit us to accurately predict the probability of vowel contact in Yoruba. Since we are dealing with verb-noun contractions, we shall focus our attention on restrictions that concern the final position (of the verb) and the initial position (of the noun). A seven-vowel system will, therefore, present seven-squared $\left(7^{2}\right)$ possibilities, that is, forty-nine (49) different kinds of combinations. But then, it has been observed that the vowel / $/ \mathrm{d}$ does not occur in the initial position of a word (see Awobuluyi [1967] among others). Therefore, the actual number of combinations permissible in the language is derivable as follows:
(2)
$7^{2}=49-7=42$ combinations
(p) (np) (a)
$\mathrm{p}=$ "possible"; $\mathrm{np}=$ "non-permissible"; $\mathrm{a}=$ "actual"

${ }^{2}$ We are limiting ourselves to the oral vowels alone for operational reasons. Akinlabi [1982], for example, considers nasality to be autosegmental in Yoruba. If he is right, then our analysis is bound to become more complex (since we would be dealing simultaneously with two autosegments: vowel and nasality), if we were to consider nasalized vowels.

${ }^{3}$ According to Bamgbose [1966], Standard Yoruba is a koine, which is used among speakers of different dialects, and it is the form used on radio and television by newscasters. Although it is largely based on the Oyo dialect, it is quite distinct and is associated with the urbanized Yorubas.

${ }^{4}$ The Standard Yoruba orthographic symbols $\stackrel{e}{e}$ and 9 represent IPA $\varepsilon$ 
2.3. Vowel contraction. Having established at the pre-contraction level the actual number of permissible combinations of vowels (in verb-noun concatenations) in Yoruba, we may now proceed to categorize these combinations. In other words, we would like to be able to predict what should happen in each case. In order to do this, we will rely on data obtained from our 1979 experimental phonetics research. 5 A comparative study of "deliberately slow" and "normal" speech reveals that, based on their comportment on contact with one another, Yoruba oral vowels may be divided into two groups: the high and the non-high:

[+high] [-high]

$/ \mathrm{i} /$ and $/ \mathrm{u} /$ lel, /o/, lẹ/, /ọ/ and /a/

2.3.1. Contact between [-high] and [thigh] vowels. We have observed that a [-high] vowel usually absorbs either of the [thigh] vowels. A simple contraction rule (CR I) may be formulated as follows:

(4) CR I:

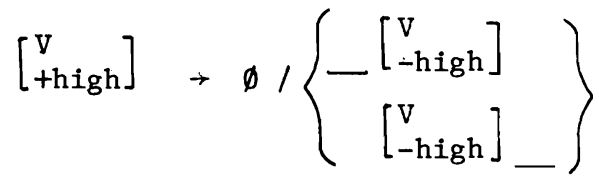

CR I above would apply in such combinations as those in (5) and (6):

(5) gé igi cut tree

(6) rí abà $\rightarrow$ rábà see farmhouse

However, there are some apparent exceptions to which we shall return short1y. In the meantime, it will be observed that the rule in (4) deals with combinations involving inter-group contact. Of the 42 combinations postulated in

and $\supset$ respectively.

5 This project was undertaken in connection with my Master of Arts thesis at the Université de Montréal. It involved an analysis of two distinct types of recordings: one in which the speech of those recorded is deliberately slow, so as to be able to isolate individual words in the sentence, whilst the other type of recording involved "normal" speech, that is, speech at the pace of the average native speaker. 
(2), there will be only 15 types (10 involving /i/ and 5 involving / / , since the latter does not occur in word-initial position). This means that we have to consider intra-group contacts in order to account for the 27 remaining types of combination.

2.3.2. Contact involving identical vowels. 6 of the intra-group contacts involve identical vowels. For example:

\begin{tabular}{|c|c|c|c|}
\hline ) a. & $\begin{array}{l}\text { ji } \\
\text { steal }\end{array}$ & $\begin{array}{l}\text { igi } \\
\text { wood }\end{array}$ & $\rightarrow \quad j i ́ g i$ \\
\hline b. & $\begin{array}{l}\text { gbé } \\
\text { carry }\end{array}$ & $\begin{array}{l}\text { ewé } \\
\text { leaf }\end{array}$ & $\rightarrow$ gbéwé \\
\hline c. & $\begin{array}{l}\text { je } \\
\text { eat }\end{array}$ & $\begin{array}{l}\text { èjjè } \\
\text { blood }\end{array}$ & - jệ̣̀ \\
\hline d. & $\begin{array}{l}\text { pa } \\
\text { kil1 }\end{array}$ & $\begin{array}{l}\text { a ja } \\
\text { dog }\end{array}$ & $\rightarrow$ pajá \\
\hline
\end{tabular}

(We would rather talk of a "reduction" than a "contraction" here since both vowels in contact are identical.)

2.3.3. Contact involving [+high] vowels. There is the case of intra-group contact between the [+high] vowels. There is only one possible combination here (because of the restriction on the distribution of $/ u /$ ). That is, the case in which the verb ends in $/ u /$ and the noun starts with $/ i /$, e.g.

$$
\begin{array}{ll}
\text { ru illù } & \rightarrow \text { rùlù } \\
\text { carry drum }
\end{array}
$$

A contraction rule (CR II) that governs this contact is formulated in (9):

(9) CR II:

$$
\left[\begin{array}{l}
\mathrm{V} \\
\text { +high } \\
\text {-back }
\end{array}\right] \rightarrow \emptyset /\left[\begin{array}{l}
\mathrm{V} \\
\text { +high } \\
\text { +back }
\end{array}\right]
$$

2.3.4. Contact involving [-high] vowels. The remaining 20 types of combination are intra-group contacts involving [-high] vowels. In this case, it is the relative positions of the vowels in contact that detenmine which one is to be elided: the second vowel remains, whereas the first is elided:

(10) CR III:

$$
\left[\begin{array}{l}
\mathrm{V} \\
\text {-high }
\end{array}\right] \rightarrow \emptyset /\left[\begin{array}{l}
\mathrm{V} \\
\text {-high }
\end{array}\right]
$$


Abundant examples of cases in which CR III operates may be cited:

\begin{tabular}{|c|c|c|c|c|}
\hline (11) a. & $\begin{array}{l}\text { ta } \\
\text { sell }\end{array}$ & $\begin{array}{l}\text { ẹran } \\
\text { meat }\end{array}$ & $\rightarrow$ & tẹran \\
\hline b. & $\begin{array}{l}\text { fẹ́ } \\
\text { want }\end{array}$ & $\begin{array}{l}\text { owó } \\
\text { money }\end{array}$ & $\rightarrow$ & fówć \\
\hline c. & $\begin{array}{l}\text { wá } \\
\text { look for }\end{array}$ & $\begin{array}{l}\text { èfó } \\
\text { vegetable }\end{array}$ & $\rightarrow$ & wẹffọ \\
\hline d. & $\begin{array}{l}\text { pe } \\
\text { cal1 }\end{array}$ & $\begin{array}{l}\text { ajá } \\
\text { dog }\end{array}$ & $\rightarrow$ & pajá \\
\hline e. & $\begin{array}{l}\text { jẹ } \\
\text { eat }\end{array}$ & $\begin{array}{l}\text { edé } \\
\text { shrimps }\end{array}$ & $\rightarrow$ & jedé \\
\hline f. & $\begin{array}{l}\text { kó } \\
\text { take }\end{array}$ & $\begin{array}{l}\text { èkọ } \\
\text { pap (cake) }\end{array}$ & $\rightarrow$ & kẹ́kọ \\
\hline g. & $\begin{array}{l}\text { kó } \\
\text { move }\end{array}$ & $\begin{array}{l}\text { ojà } \\
\text { market }\end{array}$ & $\rightarrow$ & kọja \\
\hline
\end{tabular}

2.4.1. Semantic Dissimilation Principle (SDP). Although rules CR I, CR II, and CR III are capable of explaining most verb-noun contractions, there are some exceptions which require an additional mechanism, the Semantic Dissimilation Principle (SDP), in order to explain their surface forms. In such cases, SDP blocks the application of the three CRs and in fact, reverses the fate of the two vowels in contact. Thus, for instance, CR II states that the vowel $/ \mathrm{i} /$ is assimilated by the vowel / $\mathrm{d} /$ when both of them are in contact (see (5) and (6)). However, it is quite possible for the rule to be reversed where SDP intervenes (we did not come across any instance of this in our research possibly because we limited ourselves to verb-noun contractions alone). Instances of the intervention of SDP were, on the other hand, seen with regard to the two other rules, CR I and CR III. For example, (12) appears to disobey CR I

$$
\begin{array}{ll}
\text { rí } & \text { ara } \\
\text { disgust } & \text { body }
\end{array}
$$

whilst (13) seems to disobey CR III

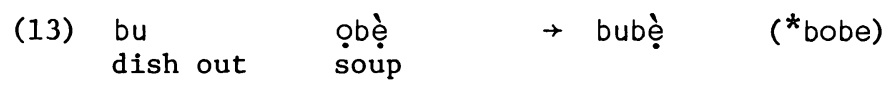

In the two cases just mentioned, our attention is focused on the post-con- 
traction structures of the phrases, and so we judge them as "non-conformists". However, an examination of their pre-contraction structures, i.e. lexical structure, shows that they would be homonymous with other structures if they obeyed the basic contraction rules. For instance, in (14) the acceptable postcontraction structure is rara, the unacceptable post-contraction structure in (12):

(14) $\begin{array}{ll}\text { ra } & \text { ara } \\ \text { rub } & \text { body }\end{array}$

And in the case of (13), the unacceptable output bọbẹ becomes the acceptable one in (15):

(15) bo
cover sọ̀ $\rightarrow$ bọbẹ

In other words, apparent exceptions to our rules are explicable in terms of dissimilatory necessity. Compare (i) to (ii) in each case presented in (16) below:

\begin{tabular}{|c|c|c|c|c|c|c|c|c|}
\hline \multirow{2}{*}{\multicolumn{2}{|c|}{ (16) $\mathrm{a}$. }} & (i) & $\begin{array}{l}\text { bi } \\
\text { born }\end{array}$ & $\begin{array}{l}\text { omọ } \\
\text { child }\end{array}$ & $\rightarrow$ & *bọmọ & $\rightarrow$ & bímo \\
\hline & & (ii) & $\begin{array}{l}\text { bó } \\
\text { feed }\end{array}$ & $\begin{array}{l}\text { omo } \\
\text { child }\end{array}$ & $\rightarrow$ & bọ́mọ & & \\
\hline \multirow{2}{*}{\multicolumn{2}{|c|}{ b. }} & (i) & $\begin{array}{l}\text { dú } \\
\text { kil1 }\end{array}$ & $\begin{array}{l}\text { ẹran } \\
\text { animal }\end{array}$ & $\rightarrow$ & *dẹran & $\rightarrow$ & dúran \\
\hline & & (ii) & $\begin{array}{l}\text { do } \\
\text { have sex }\end{array}$ & $\begin{array}{l}\text { eran } \\
\text { animal }\end{array}$ & $\rightarrow$ & dẹran & & \\
\hline \multirow{2}{*}{\multicolumn{2}{|c|}{ c. }} & (i) & $\begin{array}{l}\text { rú } \\
\text { stir up }\end{array}$ & $\begin{array}{l}\text { omi } \\
\text { water }\end{array}$ & $\rightarrow$ & *rómi & $\rightarrow$ & rúmi \\
\hline & & (ii) & $\begin{array}{l}\text { rí } \\
\text { see }\end{array}$ & $\begin{array}{l}\text { omi } \\
\text { water }\end{array}$ & $\rightarrow$ & rómi & & \\
\hline & d. & (i) & $\begin{array}{l}\text { tu } \\
\text { paddle }\end{array}$ & $\begin{array}{l}\text { okò } \\
\text { boat }\end{array}$ & $\rightarrow$ & *tọkọ & $\rightarrow$ & tukọ \\
\hline & & (ii) & $\begin{array}{l}\mathrm{ti} \\
\text { push }\end{array}$ & $\begin{array}{l}\text { okò } \\
\text { vehicle }\end{array}$ & $\rightarrow$ & tọkọ & & \\
\hline
\end{tabular}




\begin{tabular}{|c|c|c|c|c|}
\hline e. (i) & $\begin{array}{l}\text { fé } \\
\text { pillfering }\end{array}$ & $\begin{array}{l}\text { ơwọ́ } \\
\text { hand }\end{array}$ & - * fọ́wọ́ & $\rightarrow$ fẹ́wọ́ \\
\hline (ii) & $\begin{array}{l}\text { fá } \\
\text { scrape }\end{array}$ & $\begin{array}{l}\text { ơwọ́ } \\
\text { hand }\end{array}$ & $\rightarrow$ fọ́wọ́ & \\
\hline f. (i) & $\begin{array}{l}\text { ra } \\
\text { rub }\end{array}$ & $\begin{array}{l}\text { ęsè } \\
\text { ieg }\end{array}$ & $\rightarrow$ *rẹsẹ & $\rightarrow$ rasẹ \\
\hline (ii) & $\begin{array}{l}\text { ra } \\
\text { buy }\end{array}$ & $\begin{array}{l}\text { ęsè } \\
\text { ieg }\end{array}$ & rẹsẹ & \\
\hline
\end{tabular}

It will be observed that the appropriate contraction rule is blocked in (i), whereas the corresponding (ii) complies with the $C R$ in each case. In (16ai, bi, ci, di), it is our CR I that is blocked, whereas in (16ei, $f i$ ) it is CR III that is blocked.

\section{Conclusion}

Vowel contraction in verb-noun combinations depends largely on the intrinsic qualities of the vowels themselves. The 42 actually possible combinations are governed basically by three phonological rules, CRI, II, and III. So, for example,

$$
\begin{aligned}
& \text { CR I: } \quad\left\{\begin{array}{l}
1 \ldots i+e \ldots 1 \\
1 \ldots e+i \ldots l
\end{array}\right\} \rightarrow[\ldots \\
& \text { CR II: I_u } \\
& \text { CR III: }\left\{\begin{array}{ll}
1, e+a \ldots 1 & \rightarrow[\ldots a \ldots] \\
1, a+e \ldots 1 & \rightarrow[\ldots e]
\end{array}\right\}
\end{aligned}
$$

Nevertheless, a supplementary semantic principle (SDP) predicts that in certain cases, these well-motivated rules will not apply. It must be noted, however, that whereas the CR's apply at the Deep Structure Level, the SDP applies only at the Surface Structure Level. The mechanisms of the application of the latter may belong to the unconscious part of the native speaker competence, unless future research is able to prove otherwise. 


\section{REFERENCES}

Akinlabi, Akinbiyi M. 1982. "The phonological nature of Yoruba tone." Paper presented to the 3rd Annual Conference, Linguistic Association of Nigeria, University of Ilorin, August 18-21, 1982.

Awobuluyi, A. 0. 1967. "Vowel and consonant harmony in Yoruba." Journal of African Languages 6:1-8.

Badejo, B. R. 1979. "Assimilation des voyelles orales du yoruba." M.A. Thesis, Université de Montréal.

Badejo, B. R. 1983. "La topicalisation en yoruba." In Jonathan Kaye (ed.), Current Approaches to African Linguistics, Vo1. II, pp. 237-243. Dordrecht: Foris Publications.

Bamgbose, A. 1965. "Assimilation and contraction in Yoruba." Journal of West African Languages 2(1):21-27.

Bamgbose, A. 1966. A Grammar of Yoruba. West African Languages Monographs, No. 5. Cambridge: Cambridge University Press.

Bamgbose, A. (ed.) . 1972. The Yoruba Verb Phrase: Papers of the Seminar on the Yoruba Verb Phrase. Ibadan: Ibadan University Press.

Bowen, T. J. 1858. Grammar and Dictionary of the Yoruba Language. Washington D. C.: The Smithsonian Institution.

Courtenay, K. 1969. "A generative phonology of Yoruba." PhD Dissertation. University of California, Los Angeles. [No. 09-7238, University Microfilms, Inc., Ann Arbor, Michigan.]

Oyelaran, 0. 1972. "Some hackneyed aspects of the phonology of the Yoruba verb phrase." In Bamgbose [1972], pp. 163-196.

Rowlands, E. C. 1954. "Types of word junction in Yoruba." Bulletin of the School of Oriental and African Studies 6:376-388.

Rowlands, E. C. 1969. Teach Yourself Yoruba. London: English Universities Press.

Schane, S. A. 1973. Generative Phonology. Englewood Cliffs, N.J.: PrenticeHa11, Inc. 